\title{
Optimized extraction conditions of polysaccharides from Pseuderanthemum crenulatum (Wall. ex Lindl.) Radlk.
}

\author{
Nghiên cứu các điều kiện thích hợp chiết xuất polysaccharide tù̀ cây Xuân hoa \\ răng Pseuderanthemum crenulatum (Wall. ex Lindl.) Radlk.
}

Research article

Vo Hoai Bac ${ }^{*}$, Do Van $\mathrm{Hai}^{2}$, Le Van Truong ${ }^{1}$

${ }^{1}$ Institute of Biotechnology, Vietnam Academy of Science and Technology (VAST), 18 Hoang Quoc Viet, Cau Giay, Ha Noi, Vietnam; ${ }^{2}$ Institute of Ecology and Biological Resource, VAST, 18 Hoang Quoc Viet, Cau Giay, HaNoi, Vietnam.

\begin{abstract}
Polysaccharide has attracted great attentions for its benefits to human health. Polysaccharide from natural sources have diverse anti-inflammatory, anticoagulant and wound healing activities. Polysaccharide is not only valuable in medicine, also widely used in foodstuffs such as gel thickening or emulsifying agents, emulsifiers, fillers. Recently there has been an increase in the demand for polysaccharides, so research into new sources of polysaccharide with plant-based bio-activity is essential. Pseuderanthemum crenulatum (Wall. ex Lindl.) Radlk belong to genus of Pseuderanthemum. Common names (Vietnamese): Xuân hoa răng. This species is native in the forests of Vietnam. The polysaccharide content in P. crenulatum leaves was $(7.47 \pm 0.6) \%$ in dry weight. The appropriate polysaccharide extraction conditions were determined: material/ water ratio $(1 \mathrm{~g} / 25 \mathrm{ml})$, extracted temperature of $60^{\circ} \mathrm{C}$, extraction time 12 hours. The polysaccharide composition was purified by TCA $10 \%$, with a purity of $(55.6 \pm 1.19) \%$.
\end{abstract}

Trong nhũng năm gần đây, polysaccharide là nhóm hợp chất rất được các nhà khoa học trên thế giới quan tâm do các tác dụng quan trọng của chúng về tăng cuò̀ng miến dịch, kháng viêm, làm lành vết thưong, chống ung thu... Polysaccharide không nhũng có giá trị trong Y học mà còn được sủ dụng rộng rãi trong thực phẩm nhu các chất tạo độ đặc hay tạo gel, chất làm bền nhũ tuơng, chất độn... Hiện nay, nhu cầu sủ dụng polysaccharide tù thục vật ngày càng gia tăng nên việc điều tra, khai thác nguồn polysaccharide mới có hoạt tính sinh học là rất cần thiết. Pseuderanthemum crenulatum (Wall. ex Lindl.) Radlk thuộc chi Pseuderanthemum sp, tên thông thuờng là cây Xuân hoa răng, là cây mọc tụ nhiên trong rùng Việt nam. Trong nghiên cứu này, chúng tôi đã tách chiết, xác định hàm lượng và tinh sạch so bộ polysaccharide tù lá cây Pseuderanthemum crenulatum. Hàm luợng polysaccharide trong lá cây Xuân hoa răng đạt $(7.47 \pm 0.6) \%$ trọng luợng khô. Các điều kiện chiết rút polysaccharide thích hợp đã được xác định: nhiệt độ chiết rút $60^{\circ} \mathrm{C}$, tỷ lệ nguyên liệu/nuoớc ( $1 \mathrm{~g}$ mẫu khô/25ml nước), thời gian chiết rút 12 giờ. Chế phẩm polysaccharide đã được tinh sạch bằng TCA 10\%, có độ sạch đạt (55.6 \pm 1.19$) \%$.

Keywords: Extraction, polysaccharide, Pseuderanthemum crenulatum

\section{Introduction}

Polysaccharides, a type of macromolecule carbohydrate polymer, are found in a host of herbal plants and fungus $[5 ; 10 ; 12]$. During past decades, more and more attentions were focused on it allowing for its multiple functional compounds and their bioactivities which will no doubt make a contribution to the potential and promising applications in the area of food, materials and pharmaceu- ticals. Polysaccharides have many general beneficial effects for human health and therefore been developed into potential cosmeceuticals and nutraceuticals. Polysaccharide from natural sources have diverse antiinflammatory, anticoagulant and wound healing activities [13; 3]. The polysaccharides such as beta-glucans [14], pectin [7], group galactomannan [11] are more antiinflammatory effective. Polysaccharides from several medicinal plants have been shown to stimulate prolifera- 
tion of keratinocytes and dermal fibroblasts [2]. Recently there has been an increase in the demand for polysaccharides, so research into new sources of polysaccharide with plant-based bio-activity is essential.

Pseuderanthemum crenulatum (Wall. ex Lindl.) Radlk belong to Pseuderanthemum. Common names in Vietnamese is Xuân hoa răng. The species is native to China, India, Laos, Malaysia, Thailand and Vietnam where it lives in the forests. This species usually does not surpass the $1-3 \mathrm{~m}$ of height. The body is dark brown, fluffy. Petiole 1-4 cm long, with fluffy. Leaf-oval to ovate margin, size $5-15 \times 3-5,5 \mathrm{~cm}$, top face light green and feathery along the veins, with less feathering surface. Cluster of towers size $3-10 \mathrm{~cm}$, carrying thick flowers. racemose terminal inflorescences, up to $12 \mathrm{~cm}$ long, with a crowd of bilabiate flowers, of about $2,5 \mathrm{~cm}$ of diameter, pale blue to lilac with a white spot at the centre of the lower lip, that open gradually [8].

Pseuderanthemum genus belongs to the Acanthacea family have 9 species in Vietnam, but only 2 species $(P$. palatiferum and $P$. carruthersii var. atropurpureum) are used to treat and prevent many diseases, especially the anti-inflammatory and wound healing effect. However, the research on effective constituents from Pseuderanthemum genus has mainly been focused on smallmolecular compounds. Leaves of $P$. crenulatum has a very high viscosity. Therefore, the investigation and exploitation of polysaccharide source from this plant will provide new scientific information on the source of medicinal herbs in Vietnam.

Very limited work has been done on polysaccharide of Pseuderanthemum sp which calls for a more detailed research. The aim of this paper was to determine the optimal extract conditions using water extract by considering some factors: temperature, heating time and sample to water ratio.

\section{Materials and methods}

\subsection{Materials}

Pseuderanthemum crenulatum (Wall. ex Lindl.) Radlk were collected in Hien Chung commune, Quan Hoa district, Thanh Hoa province on the $6^{\text {th }}$ October 2017. Samples were kept in the Herbarium, Institute of Ecology and Biological Resources, Vietnam Academy of Science and Technology, Ha Noi, Vietnam. Sample (code DVH 171) was identified by Dr. Do Van Hai.

The standard glucose and phenol (Sigma-Aldrich Chemical Co., USA), sulfuric acid and trichloroacetic acid (TCA) (Merck); UV/VIS Spectrophotometer (Shimazu, Japan ) were used in analysis.

\subsection{Methods}

Extraction of polysaccharides preparation: $1.00 \mathrm{~g}$ of dried and shattered $P$. crenulatum was weighed to dip into water at certain ratios ranging $(1 / 15 ; 1 / 20 ; 1 / 25 ; 1 / 30 \mathrm{~g} / \mathrm{ml}$ (sample/water).
Five groups of the mixture were heated at different temperature $\left(50,60,70,80\right.$ and $\left.90^{\circ} \mathrm{C}\right)$ with constant stirring for set times $(3,6,9,12,15 \mathrm{~h})$. To obtain the crude polysaccharide, ethanol was applied for precipitation with ratio of $3 / 1$ (ethanol/sample). The depurated sediments were dried at the temperature of $60^{\circ} \mathrm{C}$ and the polysaccharides were obtained for further analysis.

UV spectrometer detection preparation: phenol-sunlfuric acid method was used to determine the polysaccharide content [4]. It is necessary to make sure that the detection with UV spectrometer can finish in a set time after polysaccharides extraction, for the color would change with time lasting.

Standard curve: Glucose was used to obtain a standard curve. The glucose solutions at concentrations of 0,25 , $50,75,100 \mu \mathrm{g} / \mathrm{ml}$ were prepared to test by the sulfuric acid -phenol method.

Deproteination by TCA method [9]: Deproteination of crude polysaccharides by trichloroacetic acid method: removed protein by TCA 5\%,10\%. The mixture was kept at $4^{\circ} \mathrm{C}$ for $4 \mathrm{~h}$, then centrifuged to remove the precipitate.

Polysaccharide Spectrophotometry: Polysaccharide extraction was performed on a spectrophotometer using the method of Liang et al [6]. Polysaccharide after extraction is diluted with distilled water at a concentration of 100 $\mu \mathrm{g} / \mathrm{ml}$ and then scanned with a UV-vis spectrophotometer (Shimazu, Japan) at a wavelength of 200 to $700 \mathrm{~nm}$.

\section{Statistical analysis}

All extractions were performed in triplicate. The apparent content of polysaccharide obtained at different conditions were analysed and expressed as mean \pm standard deviation. $\mathrm{T}$ test were used to determine the differences amongst the means. $p$-values $<0.05$ were considered to be significantly different.

\section{Results and discussion}

\subsection{Effect of temperature on the extracted amount}

Based on the published plant polysaccharide extraction studies $[1 ; 15]$, polysaccharide from $P$. crenulatum was extracted by distilled water. The extraction ratio increased with increasing temperature to $70^{\circ} \mathrm{C}$ and decreased with further increases in temperature (Fig.1). At the temperatures between $50-70^{\circ} \mathrm{C}$, the concentration of polysaccharide extracted increased at a relative stable speed. This suggests that the higher the temperature is, the greater the level of destruction of the cell wall. There were no significant differences when extracted at $60^{\circ} \mathrm{C}$ and $70^{\circ} \mathrm{C}$ $(\mathrm{p}>0.05)$.

Therefore, $60^{\circ} \mathrm{C}$ was fixed as a constant parameter for the subsequent experiments. This temperature also suitable for high temperature studies for extracting polysaccharides. However, increasing the extraction temperature to 
$90^{\circ} \mathrm{C}$ can lead to evaporation of solvents, energy costs, and more contaminants.

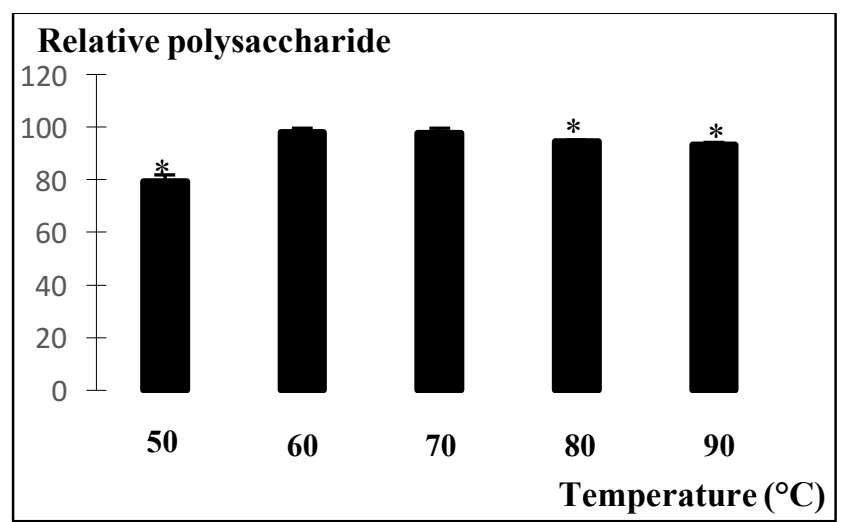

Figure 1. Effect of the extraction temperature on the polysaccharide content. (sample/water ratio $=1 / 20$; $(\mathrm{g} / \mathrm{ml})$, time $=6 \mathrm{~h}) *=p<0.05$ vs $60^{\circ} \mathrm{C}$

\subsection{Effect of extraction time on extraction of polysaccharide}

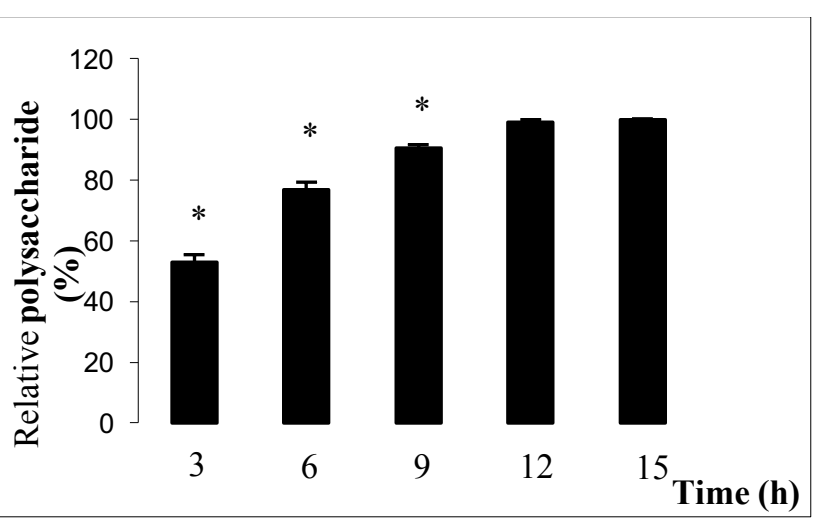

Figure 2. Effect of the extraction time on the polysaccharide content. (sample/water ratio $=1 / 20(\mathrm{~g} / \mathrm{ml})$, temp. $\left.=60{ }^{\circ} \mathrm{C}\right) *=p<0.05$ vs $12 \mathrm{~h}$

The heating time plays a major role in the polysaccharides extraction efficiency. In this study, the polysaccharides distributing in the cell of plants require time to dissolve in water. Therefore, the heating $\left(60^{\circ} \mathrm{C}\right)$ time was examined over the range of 3-15 h (Fig. 2). The highest peak was observed after heating for $12 \mathrm{~h}$. There were no significant differences when extracted at $12 \mathrm{~h}$ and $15 \mathrm{~h}(\mathrm{p}>0.05)$. Therefore, $12 \mathrm{~h}$ was selected for the optimal heating progressing.

\subsection{Effect of sample/water ratio on extracted amount}

The extraction rate was also related to sample/water ratio. Large volumes of solvent are not only uneconomical but can also influence the extract efficiency. Higher solvent extraction rates will make the extraction process faster, low density and viscosity will facilitate the release of polysaccharide molecules in water, the amount of polysaccharide dissolved in higher extracts. A series of extractions were carried out at different sample/water ratios $(1 / 15,1 / 20,1 / 25,1 / 30)$ to evaluate its effect (Figure 3 ).

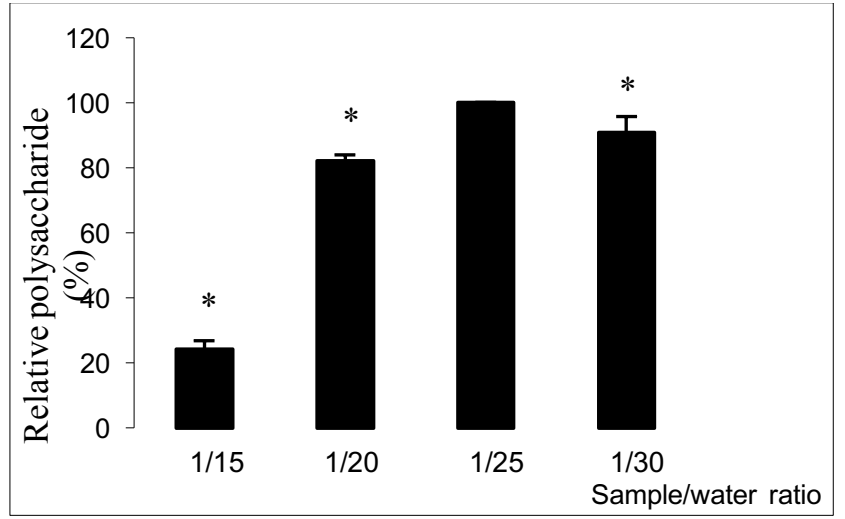

Figure 3. Effect of sample/water ratio on the polysaccharide content $\left(\right.$ temp. $=60{ }^{\circ} \mathrm{C}$, time $\left.=12 \mathrm{~h}\right),{ }^{*}=p<$ 0.05 vs $1 / 25$ (sample/water)

With increasing amount of water, the leaching-out rates is elevating until the sample/water ratio reaches to $1 / 25$ $\mathrm{g} / \mathrm{mL}$ and decreased with further increases in rate. Therefore, the ratio of $1 / 25 \mathrm{~g} / \mathrm{mL}$ was considered as the optimal ratio choice for next testes.

Due to the multiple bioactivities and extended medical applications of polysaccharides extracting from different edible nature plants, the most efficient method and conditions for the extraction acting as the most important preparation for further separation and activities study were urgent to figure out. Based on the whole experiment, the optimal parameters were $60^{\circ} \mathrm{C}, 1 / 25$ of ratio of dried sample to water and heating time of $12 \mathrm{~h}$. According to the results, the polysaccharide content in $P$. crenulatum leaves was $(7,47 \pm 0,6) \%$ in dry weight.

\subsection{Deproteination}

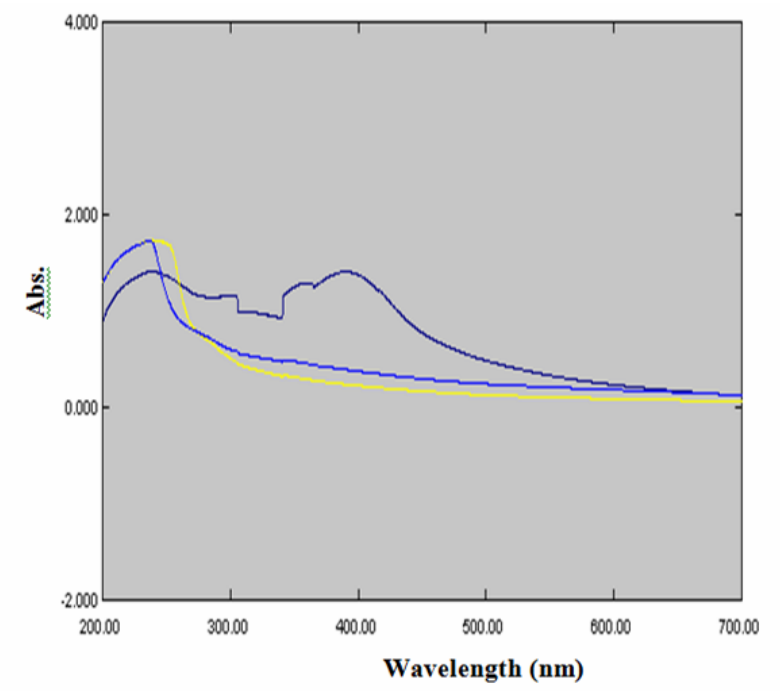

Figure 4. The UV absorbance spectra of polysaccharide before and after purification by TCA

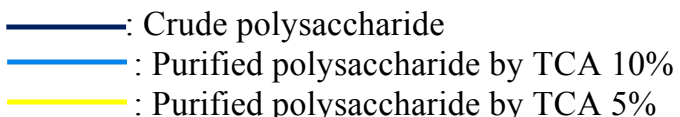

P. crenulatum was extracted with water $\left(60^{\circ} \mathrm{C}, 1 / 25\right.$ of ratio of dried sample to solution and heating time of $12 \mathrm{~h}$ ) and precipitated with ethanol (1V extracted polysaccha- 
ride $/ 3 \mathrm{~V}$ ethanol). To remove the proteins in crude extracts, TCA was added to the extract as described in the methods section. The purified polysaccharides after treatment with TCA were evaluated for purity by UV-vis spectrophotometer. Samples were scanned at a wavelength of 200-700 $\mathrm{nm}$ [9].
The UV-visible spectra (Figure4) showed that purified polysaccharides by TCA had an absorption peak at 210 $\mathrm{nm}$ only, which is the characteristic UV absorption peak for a polysaccharide. Purified polysaccharide by TCA $10 \%$ has higher purity than purified polysaccharide by TCA 5\% (table 1).

Table 1. Deproteination of polysaccharides extracts from $\boldsymbol{P}$. crenulatum

\begin{tabular}{ccc} 
Characteristics & $\begin{array}{c}\text { Polysaccharide were re- } \\
\text { moved protein by TCA 5\% }\end{array}$ & $\begin{array}{c}\text { Polysaccharide were removed protein } \\
\text { by TCA 10\% }\end{array}$ \\
\hline$\%$ yield (g/100 g dry weight) & $1.33 \pm 0,15 \%$ & $1.25 \pm 0.13 \%$ \\
Polysaccharides determination & $47.4 \pm 1,65 \%$ & $55,6 \pm 1,19 \% *$
\end{tabular}

Note: $*=p<0.05$ vs removed protein by TCA $5 \%$.

\section{Conclusion}

In this study, we extracted and determined the polysaccharide content from the leaves of Pseuderanthemum crenulatum (Wall. ex Lindl.) Radlk was $(7.47 \pm 0.6) \%$ in dry weight. The appropriate polysaccharide extraction conditions were determined as: material/water ratio $(1 \mathrm{~g} / 25 \mathrm{ml})$, extracted temperature of $60^{\circ} \mathrm{C}$, extraction time 12 hours. The polysaccharide composition was purified by TCA $10 \%$, with a purity of $(55.6 \pm 1.19) \%$.

Acknowledgement: This research was supported by Vietnam National Foundation for Science and Technology Development (NAFOSTED) under grant number 106NN.02-2015.54

\section{References}

[1] Aoxue L and Yijun F (2011). In vitro Antioxidant of a Water-Soluble polysaccharide from Dendrobium fimhriatum Hook.var.oculatum Hook. International Journal of Molecular Sciences., 12(6), 4068-4079.

[2] Deters A, Zippel J, Hellenbrand N, Pappai D, Possemeyer C, Hensel A (2010). Aqueous extracts and polysaccharides from Marshmallow roots (Althea officinalis L.): cellular internalisation and stimulation of cell physiology of human epithelial cells in vitro. J Ethnopharmacology., 127(1), 62-9.

[3] Dourado F, Madureira P, Carvalho V, Coelho R, Coimbra MA and Vilanova M (2004). Purification, structure and immunobiological activity of an arabinan-rich pectic polysaccharide from the cell walls of Prunus dulcis seeds. Carbohydr Res., 339, $2555-$ 2566.

[4] Dubois M, Gilles KA, Hamilton JK (1956). Colorimetric method for determination of sugars and related substances: Anal. Chem., 28, 350-356.

[5] Le K, Chiu F, Ng K (2007). Identification and quantification of antioxidants in Fructus lycii. Food Chem., 105, 353-63.

[6] Liang F, Xiao BJ, Feng S, Yan Ch (2010). Identification of two polysaccharides from Prunella vulgaris L. and evaluation on their anti-lung adenocarcinoma activity. Molecules., 15, 5093-5103.
[7] Lim BO, Lee SH, Park DK, Choue RW (2003). Effect of dietary pectin on the production of immunoglobulins and cytokines by mesenteric lymph node lymphocytes in mouse colitis induced with dextran sulfate sodium. Biosci Biotechnol Biochem, 67, 1706-1712.

[8] Nguyen Khac Khoi, Do Van Hai (2016). Taxonomic study on Pseuderanthemum Radlk (Acanthaceae) in flora of Vietnam. The 6th National scientific conference on ecology and biological resources: 193-199.

[9] Oliveira R, Marques F, Azeredo J (1999). Purification of polysaccharides from a biofilm matrix by selective precipitation of proteins. Biotechnol Tech., 13, 391-393.

[10] Palacios I, Garci'a-Lafuente A, Guillamón E, Villares A (2012). Novel isolation of water-soluble polysaccharides from the fruiting bodies of Pleurotus ostreatus mushrooms. Carbohydr Res; 358, 72-7.

[11] Santander SP, Aoki, Hernandez JF, Pombo M, Moins TH, Mooney N, Fiorentino S (2011). Galactomannan from Caesalpinia spinosa induces phenotypic and functional maturation of human dendritic cells. International Immuno-pharmacology; 11, 652660 .

[12] Tian LM, Zhao Y, Guo C, Yang XB (2011). A comparative study on the antioxidant activities of an acidic poly-saccharide and various solvent extracts derived from herbal Houttuynia cordata. Carbohydrate Polymes; 83, 537-44.

[13] Ukai S, Kiho T, Hara C (1983). Polysaccharides in fungi. XIV. Anti-inflammatory effect of the polysaccharides from the fruit bodies of several fungi. Pharmacobiodyn, 6(12), 983-990.

[14] Vetvicka V, Vashishta A, Saraswat OS, Vetvickova $\mathrm{J}$ (2008). Immunological effects of yeast- and mushroom-derived beta-glucans. J Med Food, 11, 615622 .

[15] Zhang ZF, Lv GY, He WQ, Shi LG, Pan HG, Fan LF (2013). Effects of extraction methods on the antioxidant activities of polysaccharides obtained from Flammulina velutipes. Carbohydrate Polymers., 98, 1524-1531. 